\title{
Export Trade Incentive Schemes Nexus Export Performance in Ethiopia
}

\author{
Aynalem Bekele Gemeda \\ Ethiopian Customs Commission, Other manufacturer and foreign trade support senior expert, Addis Ababa, \\ Ethiopia
}

\begin{abstract}
This paper pore over the role of export trade incentives schemes on export performance there on Economic growth. Data used in the paper is collected from different offices and websites like Ethiopian Revenue and Customs Authority, National Bank of Ethiopia, and National Bank of Ethiopia and Development Bank of Ethiopia. Data collected is analyzed using tables and correlation analysis. The result of the study revealed that government uses Fiscal as well as financial schemes as export incentives. Following the incentives the total export value and volume of major export items is increasing from time to time. Correlation analysis result shows that export value and fiscal incentives have positive relationship whereas; the correlation between export value and financial incentives is negative. The government is expected to do more in provision of both financial and fiscal incentive schemes so as to strengthen the contribution of this sector to the economy.
\end{abstract}

Keywords: Financial Incentives, Fiscal Incentive, Trade, Export, Growth, Ethiopia

DOI: $10.7176 / \mathrm{JAAS} / 68-06$

Publication date:September $30^{\text {th }} 2020$

\section{Introduction}

The theory of international trade is one of the oldest branches of the economic thought. Exporting is a major component of the international trade. Exporting hasan important role for the growth of the economic as a whole as well as for individual firms since Mercantilist era. Increasing export is a key concern for developing countries and it boost profitability; enhances production efficiency and competitiveness, developresources utilization capacity, provide employment and improve trade balances of countries' (Soprana, 2011) and (Hailu, 2012).

Generally, there are two broad types of exporting economies: merchandise/goods export and service export. Export of a good happens when there is a change of ownership from a resident to a non-resident; this does not necessarily imply that the good physically cross the frontier. However, in specific cases national accounts impute changes of ownership even though in legal terms no change of ownership take place (WTO, 2010).

Like other nations, Ethiopia has an experience both in service and goods export. But this paper looks only good export. Currently, there are about 35 goods export items in Ethiopia. Based on their value of export, the principal commodity exports are coffee, gold, oilseeds, and pulse (ECRA, 2012).

A common objective in most countries today is to find ways to increase exports. This can be achieved by encouraging exporting firms to export more and by inducing non-exporters to begin exporting (Zafar, 2006). These objectives often encountered with different barriers in penetrating into foreign market. According to Hibbert (1990), export barriers include tariff barriers, which lead increase in cost of production, informational barriers about international market and inadequate knowledge about the international market condition. In this regard, international experience suggests that problems of penetrating into international markets due to these barriers can be minimized through effective government support in the form of export promotion. Export trade incentive is the most common export promotion instrument, which is composed of financial, fiscal and other non-monetary incentives (Pfaffermayr, 1996). Yet, in providing such incentives to exports, procedures and trends need to carefully designed, implemented and assessed to minimize the considerable revenue forgone associated with such provisions (Biggs, 2007).

This paper, examines the trend of goods and service export as well as export trade incentive schemes and the role of such incentives on goods export growth in Ethiopia.

Despite the introduction of the export trade incentive schemes in Ethiopia, the export performance of the country is still low which shows the export percentage of GDP is very low comparing with Sub-Saharan African countries (ECRA, 2011; WTO, 2010). The effectiveness of export trade incentives on the growth of goods and service export of the country is still an open question. These include an intriguing question as to whether the export incentive schemes have robustly helped in improving the export of goods and services in the country.

The other wing of the study is to examine the effect of export trade incentives on the growth of goods export in Ethiopia. Here, also there are very little empirical studies conducted. Therefore, this study designed to fill such study gaps in the country and the area of the study. Hence, to address this issue, the following general guiding questions are formulated:-

* What is the trend of export goods growth in Ethiopia?

* What are the export trade incentives schemes provided to enhance goods exports in Ethiopia? 
* What is the trend of revenue forgone as a cost of export trade enhancement in Ethiopia?

$\$$ Do export trade incentive schemes have effect on growth of service and goods export in Ethiopia?

\section{Objectives of the study}

The objective of the study is to investigate therole of export trade incentive schemes on of export growth in Ethiopia. Specifically the following are the objectives.

4 To examine the trend of export growth in Ethiopia

* To identify the export trade incentive schemes provided to enhanceexport growth in Ethiopia,

$\$$ To assess trend of revenue forgone as cost of export trade enhancement in Ethiopia,

* To examine the effect of export trade incentive schemes on growth of export growth in Ethiopia.

\section{LiteraturesReview}

Export trade incentives- are the government fiscal and financial policy designed to encourage domestic firm to produce and export more to foreign market. Export incentives are all arrangements made by the government to help exporters to overcome the constraints that they may encounter in their export transactions and everything that can help a dynamic system for promoting foreign sales (Hibbert, 1990).

Having recognized the importance of export trade incentive and the existence of barriers to exporting firm's there arevarious incentive policy designed to help exporter overcame barrier and became competitive(World Bank, ITD 2009). Export trade boosts the export performance of the country in that way helps to balance the trade deficit which is one of the main problem economic developments.

De Wulf and Sokol (2005) explained that the main objective of export trade incentive is to get rid of tariff burden on inputs and to increase access to industrial input.It is true that different countries may have difference in objective priority. In most developed nations the primary objective of providing export trade incentive is to overcome the balance of trade deficit via promoting export trade but developing countries the primary objective to overcome the shortage of foreign currency. Similarly, in Ethiopia the primary aim of providing export trade incentive is to generate foreign currency earning, ensuring economic development by accelerating industrial growth of the country and to improving the foreign exchange earning needed for development and investment.

\section{Export trade incentive and economic growth}

Exporting is an import once factor of economic growth, and therefore export promotion is a critical consideration for economic development of any country. Many people strongly support export promotion strategy through incentives that benefits both developed and developing countries. Among the usual advantages of the export promotion are foreign exchange earnings, exposure of domestic firms of international market; consequently increase in their efficiency transfer of technology, generate greater capacity of resources utilization of which the economy has comparative advantage, to take advantage of economic of scale, create employment and increase labor productivity, relation of current account pressures for foreign capital goods by increasing the country's external earning and attracting foreign investment and to increase the total factor productivity and consequently the well being of the country (Emilo,2002).

Exporters need to be competitive in the world market in order to be completive, the government should support through export trade incentive which encourage greater competition and associated with productivity gains, technological knowhow and knowledge. Therefore, incentives is important to promote efficient resource allocation among sectors and to move to whole economy to competitive market.

Based on the foregoing discussion, thus, it can be concluded export promotion development polices is popular policy for achieving rapid economic growth, through diversified export which enables developing countries to accomplish stability. Export trade incentive are of different types.

The first one is Fiscal incentives that includes all measures taken to reduce disincentives to export efforts caused by duty or other change on export, duties on import required for production of exports: duties on import of materials and components required for the production of manufactured goods as well as duties on production that add un necessary cost to the selling price of export products (Hibbert, 1990). According to oyejide (2007), fiscal incentives schemes such as duty drawback and exemptions, manufacturing under bonded warehouse and establishment of export free zone are considered 'compensatory' which are targeted to eliminate disincentives raised from economy's trade, investment and exchange regimes by from economy's trade, investment and exchange regimes by assuring equal footing with foreign competitions in terms of access of input at world market prices.

The second types of incentive is financial incentives thatdesigned to make export business attractive through compensation for price disadvantage (Hibbert, 1990). Such category of incentive includes direct /indirect cash subsidies; export credit facilities for pre-shipment and post shipment transactions; special foreign exchange allocation and remission of tax normally chargeable on profit. Financial incentives enables exporters to eliminate their financial constraints (Morrissey, 2012). 
The practice of giving export incentives is nearly universal, however, the extent and the form of export incentive vary from country to country (Ahuja, 2001).According to (Lennon, 2009) manufacturers in Asia are benefited from either incentive methods and enhances their export status. In the same fashion, in South Africa the implementation of export incentives increases good export by large percent from year to year.

In Ethiopia also, the government acknowledges the importance of increasing and diversifying the country's export to ease foreign currency shortage along a free market - based economic path. The governmentrenounced taxes on nearly all variety of products exported (Geda, 2002).

There are different proclamations in Ethiopia that dictates about those incentives. Accordingly, the fiscal incentive scheme includes duty drawback scheme, voucher scheme, bounded manufacturing warehouse scheme, bonded input supplies warehouse scheme. Bounded export factory and industrial zone schemes. Financial trade incentive scheme to exporter are export credit guarantee scheme, foreign exchange retention scheme and external loan and supplier or foreign partners' credit

Generally, these are export trade incentive scheme applied by the government of Ethiopia to improve the foreign currency reserve of the country by encouraging exporters expecting its return in improving economic growth as well as economic development of the country.

\section{Methodology of the study}

The study uses atrend analysis and correlation analysis for the period 2007/08-2011/12. To conduct this study five years time series secondary quantitative data was used and the data was collected from Ethiopian revenues and customs authority(ERCA), National bank of Ethiopia (NBE), development bank ofEthiopia (DBE) and Ministry of industry (MOI).

The Export data of the country andthe fiscal export incentive data duringthe specified period were collected from the report and data base of ERCA and NBE; data related to financial incentive was collected from NBE and DBE; fiscal incentive beneficiaries and other related data were collected from MOI and real exchange rate from NBE.

In the study, the independent variables are the incentives which are the aggregate monetary and fiscal incentives provided to exporters each year in terms of local currency Birr which is found by adding the revenue forgone under each fiscal incentive schemes. Financial incentives which are the annual monetary financial incentive provided to exporters to minimize their financial problem. The dependent variables of the study is the export growth expressed in termsof export value and export volume.

\section{Trend of total export value from 2007/08-2011/12}

The trend of total export value( items like Coffee, oilseeds, Leather and leather products, Pulses, Meat and meat product, Fruits and vegetables, Live animals, Chat, Gold, Flower and others included) growth of the country shows an increment year after year. During the study period total sum of 10816.70 million dollars was obtained from goods and service export.

Table 4.1 Export value of major export items and services (Inmillions of USD)

\begin{tabular}{|l|l|l|l|l|l|l|}
\hline Export commodity and services & $2007 / 08$ & $2008 / 09$ & $2009 / 10$ & $2010 / 11$ & $2011 / 12$ & Total \\
\hline Coffee & 524.5 & 375.9 & 528.3 & 841.8 & 833.1 & 3103.6 \\
\hline Oilseeds & 218.8 & 356.1 & 358.5 & 326.6 & 472.3 & 1732.3 \\
\hline Leather and leather products & 99.2 & 75.30 & 56.4 & 103.8 & 109.9 & 444.6 \\
\hline Pulses & 143.6 & 90.70 & 130.1 & 137.9 & 159.7 & 662.00 \\
\hline Meat and meat product & 20.9 & 26.60 & 34.0 & 63.3 & 78.8 & 223.60 \\
\hline Fruits and vegetables & 12.8 & 12.10 & 31.47 & 31.5 & 44.9 & 132.77 \\
\hline Live animals & 40.9 & 52.70 & 90.7 & 147.9 & 207.1 & 539.30 \\
\hline Chat & 108.3 & 138.7 & 209.5 & 238.3 & 240.3 & 935.10 \\
\hline Gold & 78.8 & 97.8 & 281.4 & 461.7 & 602.4 & 1522.10 \\
\hline Flower & 111.8 & 130.7 & 170.2 & 175.3 & 197.0 & 785.00 \\
\hline Others & 106.3 & 91.3 & 112.5 & 219.1 & 207.1 & 736.30 \\
\hline Total & 1465.90 & 1447.90 & 2003.1 & 2747.2 & 3152.6 & 10816.70 \\
\hline
\end{tabular}

Source:National bank of Ethiopia annual report of 2007/08-2011/12 


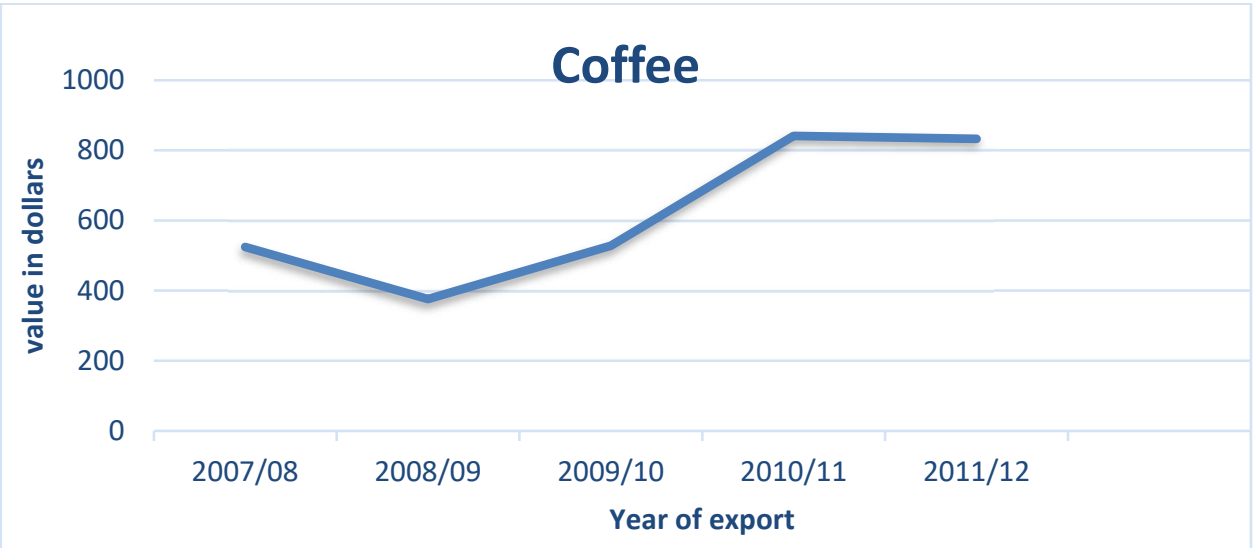

Coffee being the major exporting item shows increasing trend in value during the study period. This is contributed to arrays of export incentives that enable the exporters to increase the amount of export from time to time.

As indicated in the above table 4.1 during the period ofthestudy Ethiopian total export trade values has shown an increase from 1465.90 million dollars in 2007/08 to 3152.60 million dollars in 2011/12 with an annual average growth rate of 22.26 percent. The lowest total export value growth rate was registered in 2008/09 which was -1.23 percent and the highest growth rate was registered in 2009/10 which is 38.35 percent. From this it can be concluded that during the study period total export value of Ethiopia has a positive increment trend.

\section{Trend of total export volume from 2007/08-2011/12}

The volume of export is one aspect of countries export to generate adequate foreign currency growth has been recorded in total export volumeof Ethiopia even though it is not uniformly distributed across the different export items and fluctuated with in the period.

Table 4.2 Export volume of the different commodities from 2007/08-2011/12(in millions of KG)

\begin{tabular}{|l|l|l|l|l|l|l|}
\hline Export commodity & $2007 / 08$ & $2008 / 09$ & $2009 / 10$ & $2010 / 11$ & $2011 / 12$ & Total \\
\hline Coffee & 170.7 & 134.0 & 172.2 & 196.1 & 169.4 & 842.4 \\
\hline Oilseeds & 152.1 & 287.0 & 299 & 254.2 & 367.4 & 1359.7 \\
\hline Leather and leather products & 14.9 & 7.3 & 2.9 & 5.2 & 4.4 & 34.7 \\
\hline Pulses & 233.0 & 138.0 & 225.7 & 224.5 & 226.2 & 1047.4 \\
\hline Meat and meat product & 6.5 & 7.5 & 10.2 & 16.9 & 17.7 & 58.8 \\
\hline Fruits and vegetables & 39.9 & 38.5 & 66.3 & 91.6 & 123.5 & 359.8 \\
\hline Live animals & 40.0 & 36.7 & 90.7 & 112.8 & 144.9 & 425.1 \\
\hline Chat & 22.4 & 25.4 & 36.1 & 41 & 41.1 & 166 \\
\hline Gold & 0.0038 & 0.0049 & 0.0089 & 0.0112 & 0.0122 & 0.041 \\
\hline Flower & 22.4 & 29.2 & 36 & 41.6 & 46.8 & 176 \\
\hline Total & 701.9 & 703.61 & 939.11 & 983.91 & 1141.41 & 4469.94 \\
\hline
\end{tabular}

Source: own computation based on ERCA's data

\section{Oilseeds}

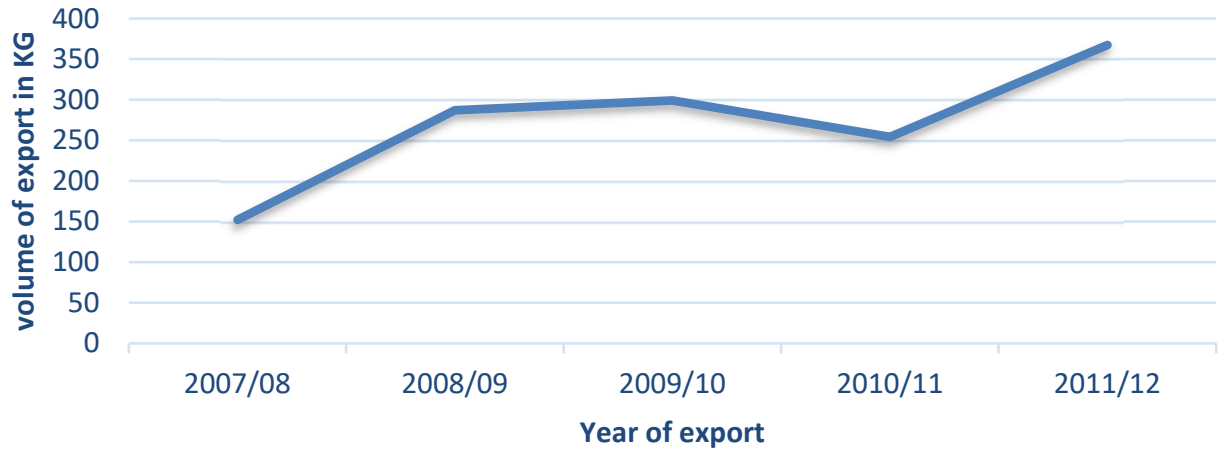

Export volume of Oilseed shows sharp increment form $152.1 \mathrm{Kg}$ in $2007 / 2008$ to $367.4 \mathrm{Kg}$ in $2011 / 2012$ as 
a result of incentives given for exporters.

An increase in export volume supported by stable price helps to generate adequate foreign currency. In the period, a total of 4469.94 million of $\mathrm{Kg}$ goods are exported to different parts of the world. Generally, it is observed that there is increasing volume of export during the period.

\section{Export trade incentive scheme in Ethiopia}

The trend of trade incentive scheme given to promote export of the country is important in order to ensure economic development and to improve foreign exchange earning needed for economic development.

\section{Fiscal export trade incentive scheme}

This incentive is the main export trade incentive scheme provided comprehensively by the government of Ethiopia. The most used fiscal incentive sachems are the duty draw Back scheme and voucher scheme.

Regarding draw back scheme, as toproclamation number 768/2012, exporters entitled to be benefited from this scheme are producer exporter wholly, partially or occasionally engaged in exporting their products; indirect producer exporters wholly, partially or occasionally supplying their products to producer exporters or exporters in the form of raw material or finished goods; raw material suppliers supplying imported raw material to producer exporters without processing it; re-exporting commodities or raw materials, they have imported upon payment of duties for being in conformity with purchase specification, damaged, short delivered.

The dutyand other direct taxes paid at the time of importation of raw materials and the VAT(value added tax) paid on domestic purchases shall be refunded to the beneficiaries of the scheme upon the fulfillment of conditions laid down in the proclamation. The refunded is expected to be made within six months from the date of the export. This creates financial constraint to the exporters since the duty and other indirect taxes paid at a time importation and acquisition of raw materials.

The trend of revenue forgone under draw back scheme

Table 4.3Fiscal export trade incentive schemes

\begin{tabular}{|l|l|l|l|l|l|l|}
\hline Year & 2008 & 2009 & 2010 & 2011 & 2012 & Total \\
\hline Amount of forgone value(in million birr) & 7.2 & 10.1 & 8.7 & 56.3 & 83.4 & 165.7 \\
\hline Number of beneficiaries(in number) & 21 & 28 & 29 & 20 & 28 & 126 \\
\hline Amount of forgone value( in million birr) & 112 & 500 & 725 & 989 & 3040 & 5366 \\
\hline
\end{tabular}

As illustrated from the above table; during the period of 2007/08-2011/12 the amount of duties and taxes forgone under the drawback scheme is 165.7 million birr. This is due to the increase in value and volume of goods export growth in the specified period. In Ethiopia this scheme is not undertaken in a well coordinated way; there is a problem regarding data of exporters and the refund amount. In addition, the time taken for refund is also not short even though there is an improvement in recent years (ERCA, 2011).

This scheme is the functional scheme which is provided for persons and organizations who have obtained legal certificate issued by the ministry of industry when fulfill the requirements specified in the proclamation and the voucher book is granted by ERCA.

The voucher scheme allows exporters to be exempted from customs duties and taxes before the importation of inputs used to produce export goods which enable exporters to access export inputs at world market price and thereby increase productivity of revenue from export. According to proclamation 768/2012, exporters who fail to export products abroad and sold to local market are liable to pay duty and taxes including penalty.

\section{Thetrend of voucher beneficiaries}

As indicated in the above table 4.3 there was 21 new exporters enterunder the voucher scheme by the year 2008 and in 2012 the total number of newly entrant to the voucher scheme beneficiaries within the five years reached 126.

During the period 2008 to 2012, the Ethiopian government has forgone a total of birr 5366 million birr through voucher scheme. The scheme has an increment trend which indicates exporters are attracted by this scheme.

\section{Financial export trade incentive scheme}

Financial export trade incentive scheme is other form of export trade promotion which is provided by the government of Ethiopia. The reason for this incentive is to minimize the financial constraint of exporters.

There are two main interrelated financial export trade incentives scheme provided by the government for exporters. Such as export credit guarantee scheme and export credit scheme according to the directive of National Bank of Ethiopia of the export credit.

Export credit guarantee scheme is one of the financial export trade incentives schemes which finance the exporters pre-shipment and post-shipment. This is a guarantee given by National Bank of Ethiopia and later developed by Development Bank of Ethiopia. The bank plays as collateral between exporters and government and 
private banks to get credit for their export activities. This enables the national exporters compete with equal footing with other exporters at international market. Table 4.4 shows that the amount of loan provided under export credit guarantee for the exporter from2008-2012. Is totaledto birr 2126 million. This loan is provided by different government and private banks.

Table 4.4 Financial export trade incentive schemes

\begin{tabular}{|l|l|l|l|l|l|l|}
\hline Year & 2008 & 2009 & 2010 & 2011 & 2012 & Total \\
\hline $\begin{array}{l}\text { Amount of loan under credit guarantee (in } \\
\text { million birr) }\end{array}$ & 721 & 608 & 332 & 265 & 200 & 2126 \\
\hline $\begin{array}{l}\text { Export credit for goods export(in million } \\
\text { birr) }\end{array}$ & 2858.52 & 5279.50 & 5936.36 & 2659.48 & 2569.05 & 19302.91 \\
\hline
\end{tabular}

Export credit is the other method of financing exports. Credit is provided for exporters as per National Bank of Ethiopia. From 2007/08-2011/12 a total of birr 19302.91million was given for loan for goods exporters. As illustrated in the table 4.4 the loan given to the exporters was increasing.

Correlation analysis between export growth and fiscal and financial incentives

Table 4.5 .Fiscal incentives and financial incentives value in birr

Year Export growth by value in birr Fiscal incentives value in birr

Financial incentives value in birr

\begin{tabular}{l|rrr}
\hline 2008 & 32249.8 & 289.08 & 8678.12 \\
2009 & 31853.8 & 1162.26 & 13413.62 \\
2010 & 44068.2 & 1186.9 & 10140.24 \\
2011 & 60438.4 & 1353.44 & 3786.2 \\
2012 & 69357.2 & 3856.16 & 3418.8
\end{tabular}

Correlation analysis between export value and fiscal incentives is computed to be 0.822 that shows there is a positive relationship during the study period. This result tell that with the increase in fiscal incentive, export also increases. In other computation,Correlation analysis between export value and financial incentivesis -0.893 which shows there is a negative relationship between the two.

\section{Conclusions}

The trend analysis revealed that the country's export earnings from goods export showsgrowth as a result of export incentives. Volume of goods exports, the average total goods export volume of a country in the specified period with a comprehensive export trade incentive scheme has shown an increment. Volume and value of export is increasing while the credit guarantee was decreasing this show that the inverse relation between the Credit guarantee and the export. The correlation analysis showed that there is a positive correlation between goods exports value and fiscal incentives, and negative relationship between value of export and financial incentives.

\section{Recommendation}

To encourage the export growth of the country, the government has to strengthen fiscal incentives and should have to reduce financial incentive schemes.

According to the study, there is a positive relationship between export fiscal trade incentive schemes and growth of export value which have impacts on economic growth. The policy implication is that policy makers should be careful in designing policies and the respective organizations should properlyImplementand administer the incentive schemes to promote export and should have continuous modernization process.

Government institutions that implement the export trade incentives should properly implement automation system to reduce the cost of exporters, to attain proper records, and fast and effective service to the exporters.

\section{References}

Biggs, Tyler, (2007). $\quad$ Assessing Export $\quad$ Supply Constraints:http://www.aercaafrica.org/documents/export_supply_working_papers/biggs_assessing.pdf

Eichengreen, Barry and Guota, Poonam. (2012) Export of Service: Indian Experience in Perspective. Working, Paper No. 2012-102. National Institute of Public Finance and Policy, New Delhi.

Emilo J., (2002). Is the Export-led Growth Hypothesis Valid for Developing Countries? A Case Study of Costarica, Policy Issues in International Trade and Commodities University of Essex, UK and Universities de Carabobo, Venezuela.

ERCA. (2011). Ethiopian: Foreign Trade and Federal Duty and Tax Revenue Collection, Statistical Bulletin (Vol.

1), Ethiopian Revenues and Customs Authority, Ethiopia

ERCA. (2012). Annual Report, Ethiopian Revenues and Customs Authority, Ethiopia.

GedaAlemayehu, (2002). Profile of Ethiopia's Export Performance, Proceedings of the Ethiopian Economic 
Association Annual Conference on the Ethiopian Economy: Ethiopian Economic Association.

HailuKiros, (2012). Determinants of Export Growth Rate in Ethiopia 1980 - 2010: co intergration and error correction model analysis. A project submitted to the school of Addis Ababa University, Ethiopia.

Hassan A. M. \& Toda H. (2007). Export Diversification and Economic Growth: the Experience of selected least developed countries, Development Paper No. 24, New York.

Hibbert (1990). Management of International Trade Promotion, London: Routledge.

IMF, (2010). International Financial Statistics Report of 2010. Retrieved from www.erf.org.eg/cms/getfile.php?id=847

Lennon C. (2009). Trade in service and trade in goods: differences and complementarities, manufacturing performance: Evidence from India.

Morrissey Oliver, (2012). Trade Policy and Performance in Sub-Saharan Africa, Africa Development bank Economic Research Working Paper

National Bank of Ethiopia (NBE). (2012). Yearly statistical bulletin. Volume 11, National Bank Ethiopia.

Oyejide T. Ademola, (2007). Africa Trade, Investment and Exchange Rate Regimes and Incentives for Exporting, AERC Research Project on Export Supply Response and Capacity Constraints in Africa, Paper No. ESWP_09.

Pfaffermayr M. (1996). Foreign outward direct investment and export in Austrain.

Samen, Salomon, (2010). A primer on export diversification: key concepts, theoretical underpinning and empirical evidence growth and crisis unit World Bank Institute.

Soprana, (2011). Services exports and developing countries: competitiveness challenges according to mode of supply; World Trade Institute.

World Bank, (2010). Global Economic Prospects 2010, World Bank, Washington DC.

World Bank, (2011). The East Asian Miracle, economic growth and public policy, published for the World Bank Oxford University Press. Working Paper 53, Vienna for International Economic Studies.

World Trade Organization, (2010). Export promotion and the WTO, International Trade Centre (ITC), Joint Agency of the World Trade Organization and the United Nations.

World Trade Organization, (2013). A Review of Statistic on Trade Flows in Services Overview of Trade Flows in Commercial Services 2009 - 2013, Council for Trade in Services, Note by the Secretariat, Addendum, $\mathrm{S} / \mathrm{C} / \mathrm{W} / 329 /$

Zafar U. Ahmed, (2006). Firm Internationalization and Export Incentive from a Middle Eastern Perspectives: Department of Marketing, College of Business and Technology, Texas: A\&M University at Commerce, Texas, USA

Declaration

$\checkmark \quad$ The submission is original,

$\checkmark \quad$ The submission is not being considered elsewhere,

$\checkmark$ There is no conflict of interests and,

$\checkmark \quad$ The author agree to grant the first editing / publishing rights to the journal upon acceptance. 